\title{
TOOTH ENAMEL MICROSTRUCTURE IN MEGASOREX GIGAS (MERRIAM, 1897) AND CRYPTOTIS MAGNA (MERRIAM, 1895) FROM MEXICO - IN COMPARISON TO THE SCHMELZMUSTER IN OTHER SHREWS
}

\author{
WIGHART V. KOENIGSWALD
}

Institut für Geowissenschaften, Abteilung Paläontologie, Rheinische Friedrich-Wilhelms-Universität Bonn, Nussallee 8, D-53115 Bonn, Germany; e-mail: koenigswald@uni-bonn.de.

Koenigswald, W. v. (2019): Tooth enamel microstructure in Megasorex gigas (Merriam, 1897) and Cryptotis magna (Merriam, 1895) from Mexico - in comparison to the schmelzmuster in other shrews. - Fossil Imprint, 75(3-4): 299-306, Praha. ISSN 2533-4050 (print), ISSN 2533-4069 (on-line).

\begin{abstract}
The enamel microstructure of molars in Mexican soricines Megasorex and Cryptotis is described and compared to the six types of schmelzmuster found in fossil and recent Soricidae. These types of schmelzmuster show a high correlation to the current systematics of Soricidae. In Megasorex, the relatively simple schmelzmuster is dominated by radial enamel. However, a very thin innermost layer of differentiated enamel indicates the beginning of a two-layered schmelzmuster. This corresponds to the Notiosorex-schmelzmuster. The teeth of Megasorex lack pigmentation, which is not reflected in its schmelzmuster. Similarities to the white-toothed Crocidura-schmelzmuster are superficial. Cryptotis has the typical two-layered enamel of derived Soricinae. The specific enamel type of the inner layer and the strong lateral inclination of its prisms represent a new modification of the highly derived Blarina-schmelzmuster.
\end{abstract}

Zusammenfassung: Die Mikrostruktur des Zahnschmelzes in den Molaren der Mexikanischen Spitzmäuse, Megasorex und Cryptotis, wird beschrieben und mit den sechs Schmelzmuster-Typen verglichen, die von den fossilen und rezenten Soriciden bekannt sind. Die unterschiedenen Schmelzmuster-Typen weisen eine sehr hohe Übereinstimmung mit der derzeitigen systematischen Gliederung der Soriciden auf. Das Schmelzmuster von Megasorex ist relativ einfach und wird von radialem Schmelz dominiert. Aber eine sehr dünne Innenschicht weist auf eine beginnende Zweischichtigkeit hin, wie sie im NotiosorexSchmelzmuster zu beobachten ist. Den Zähnen von Megasorex fehlt die Pigmentierung, die sich aber nicht auf das Schmelzmuster auswirkt. Eine gewisse Ähnlichkeit zum dem Schmelzmuster der weißzähnigen Crocidura ist nur oberflächlich. Cryptotis hat das für evoluierte Soricinae typische zwei-schichtige Schmelzmuster. Der besondere Schmelztyp der Innenschicht und die starke seitliche Neigung der Prismen belegen eine Zugehörigkeit zum hoch abgeleiteten Blarina-Schmelzmuster, wobei Cryptotis eine neue Modifikation belegt.

Key words: enamel microstructure, schmelzmuster, Soricidae, Mexico

Received: April 12, 2019| Accepted: August 20, 2019 | Issued: December 30, 2019

\section{Introduction}

The enamel microstructure in molars of Megasorex gigas and Cryptotis magna shall be compared with the variability of the enamel in soricid molars. The different tribes within Soricidae differ in their enamel microstructure (Koenigswald and Reumer 2020). The enamel in a single species is not uniform, but rather is composed of different enamel types. The three dimensional arrangement of the enamel types within a tooth is described as "schmelzmuster". The variability of the molar schmelzmuster in Soricidae was recently studied by Koenigswald and Reumer (2020). Six types of schmelzmuster in lower molars are recognized and named after typical genera: Soriciella-, Anourosorex-, Crocidura-, Notiosorex-, Sorex- and the Blarina-schmelzmuster. These types of schmelzmuster are closely related to the actual systematic order of Soricidae (Reumer 1996, 1998, Gunnell et al. 2008, Rzebik-Kowalska 2009). This broad study provides the background for the comparisons in this paper.

Megasorex gigas was not included in the former survey. Its unpigmented teeth, as well as those of the Chinese Nectogale, are unique among soricines. In addition, the impressive name Megasorex gigas causes one to question whether the schmelzmuster might be special, because of the promised size change. The name, however, refers to the 
size differences within Notiosoricini. Notiosorex crawfordi from Colorado is distinctly smaller, but in comparison to other soricines, such as the sympatric Cryptotis magna and Blarina brevicauda, the size of Megasorex magna is not exceptional (Text-fig. 1).

The different types of schmelzmuster correlate with the various soricid groups. The soricid tribe Notiosoricini contains two extant genera, Notiosorex and Megasorex, and occurs in the southern US, Mexico and the northern part of South America. In the survey by Koenigswald and Reumer (2020), only Notiosorex crawfordi from Colorado could be investigated. Here, the investigation of Megasorex shall clarify whether it shows a similar or the same schmelzmuster as Notiosorex. Notiosoricini are characterized by a reduced dental formula and the specific articular process of the mandible (Reumer 1984, 1998, Harris 1998, Hutterer 2005). Within the Soricinae, the tribes Notiosoricini and Nectogalini (= Neomyini) are sister groups (Dubey et al. 2007), but several authors do not separate the two tribes (e.g. Gunnell et al. 2008). In addition to the two extant genera Notiosorex and Megasorex, the tribe Notiosoricini contains two fossil genera, Beckiasorex and Hesperosorex. They are known from several fossil species since the Miocene (Carraway 2010), and occur in the southern US and Mexico. Megasorex HibBARD, 1950 is monospecific. The species Megasorex gigas (MERRIAM, 1897) was initially assigned to the closely related genus Notiosorex, but separated by Hibbard (1950), because of the size difference, a heavy rostrum, and the white teeth in Megasorex. In contrast, Notiosorex has pigmented tooth tips (Text-fig. 1). Their coloring may be weak, but is generally present.

Cryptotis magna was included in this study as a counterpart to Megasorex that most probably shows a different schmelzmuster. Cryptotis belongs to the soricine tribe Blarini and has pigmented tooth cusps, like most soricines (Text-fig. 1).

\section{Material and methods}

In addition to a great number of soricids that were studied for another survey (Koenigswald and Reumer 2020), the following materials were investigated especially for this study:

Megasorex gigas (Merriam, 1895) Mexico, (UNAM 43090) (KOE 4222);

Cryptotis magna (Merriam, 1895) Mexico, Colima: Rancho La Mora (UNAM 29439) (KOE 4220);

Blarina carolinensis, Tennessee (UTCM 526);

Notiosorex crawfordi, Colorado (KOE 2114 and UCM 20281).

The material of Megasorex and Cryptotis was collected in Mexico, Colima, Rancho La Mora at an elevation of 1,322 m (Cervantes et al. 2008), and was made available for this study by Fernando Cervantes-Reza from the "Colección Nacional de Mamíferos (CNMA)" of the "Instituto de Biologia, Mexico".

Investigations of enamel microstructure and comparison between taxa may occur at various levels, according to the applied techniques and magnifications: at the level of crystallites, prisms, enamel types, schmelzmuster, and at the
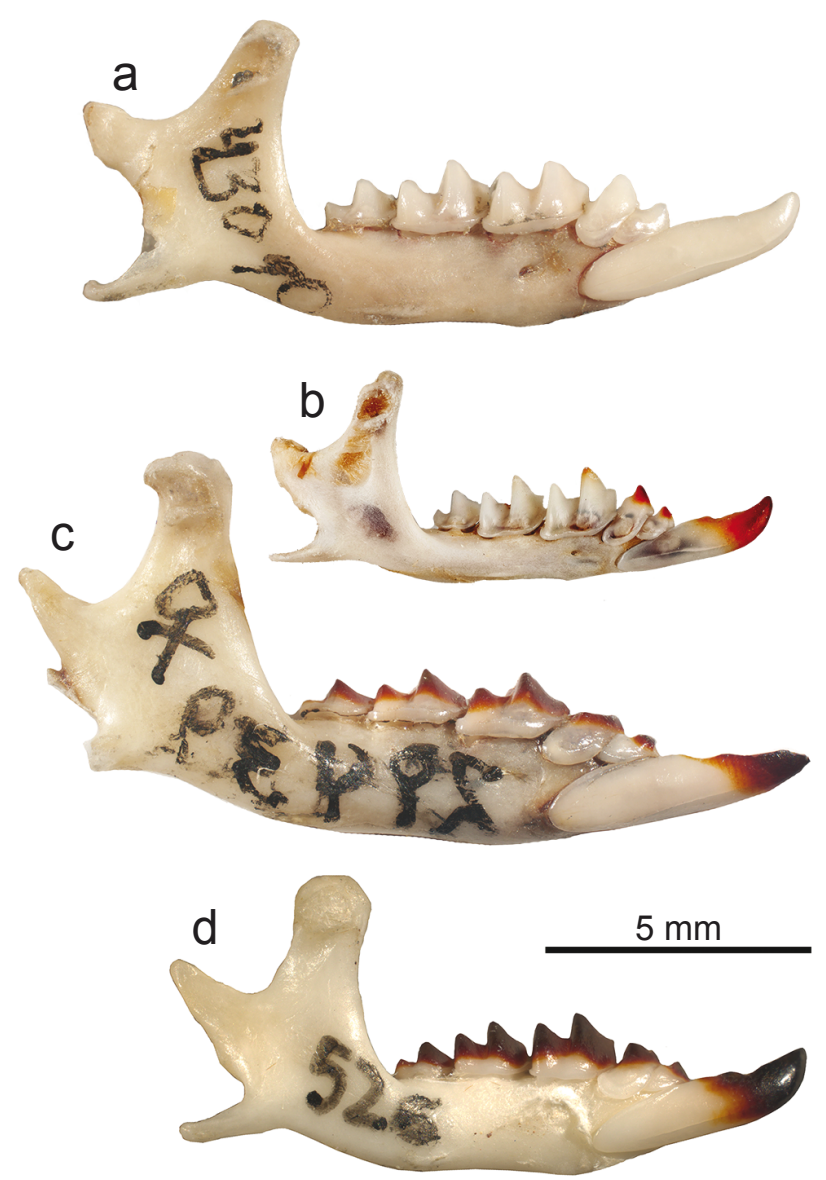

Text-fig. 1. Comparison of mandibles of Soricidae. a) Megasorex gigas, right dentary, Mexico (UNAM 43090, KOE 4222). b) Notiosorex crawfordi, right dentary, Colorado (UCM 20281). c) Cryptotis magna left dentary (inverse), Mexico (UNAM 29439, KOE 4220). d) Blarina carolinensis, right dentary (UTCM 526, KOE 4203). For the better comparison in size, all are to the same scale. Photos (a), (c) and (d) by Georg Oleschinki, (b) by Nicole Neu-Yagle.

dentition level (Koenigswald and Clemens 1992). Špoutil et al. (2010) investigated the enamel of some Eulipotyphla at the level of prism. For the actual question, the level of schmelzmuster in lower molars is adequate. According to initial observations, the schmelzmuster of upper molars is differentiated as well, but sections for comparisons are more difficult to obtain. The enlarged incisors definitely show a schmelzmuster different from that in the molars. Such differences are related to the dentition level.

The molar morphology of soricid molars is very complex. A transverse section of the trigonid of the lower molars just below the paralophid notch was selected for the comparison of soricid schmelzmuster. The arrangement of different enamel types within the trigonid can clearly be analyzed, and this section can be reproduced easily. Comparative studies of many soricids confirmed that the arrangement of enamel types in the paralophid is repeated in the protolophid and the hypolophid. Thus, the observations in transverse sections of a tooth row can be summarized in order to characterize the enamel of a species.

From Megasorex gigas as well as from Cryptotis magna, a part of the mandibles containing lower molars was 
embedded into an artificial resin (epoxy). For embedding, the specimen was oriented in such a way that the intended plane of investigation is parallel to one of the sidewalls of the box. The preferred section plane can then be reached by sectioning or grinding parallel to this side. After hardening of the resin, the block was cut with a saw in the intended plane, but slightly outside of the teeth, to avoid cracking of the enamel. Grinding was done first on a wheel, then on fine grinding paper with water, and finally with grinding powder $(1,000$ mesh $=5 \mu)$, until the level of the intended section was reached. The structure of the enamel becomes visible only after etching. After washing, a 10\% hydrochloride acid $(2 \mathrm{~mol} / \mathrm{HCl})$ was applied for about three seconds, then neutralized in water. The specimen was sputter-coated with gold and investigated in the SEM.

At a magnification of $400 \times$, the distribution of different enamel types is visible, and at $800 \times$, the orientation of the prisms and the interprismatic matrix can be studied. After documenting the enamel, the grinding, etching and sputtercoating were repeated if the pictures were not optimal, or to investigate a somewhat deeper section of enamel.

$\begin{array}{ll}\text { Abbreviations } \\ \text { EDJ } & \text { enamel-dentine junction } \\ \text { hyd } & \text { hypoconid } \\ \text { IPM } & \text { interprismatic matrix } \\ \text { med } & \text { metaconid } \\ \text { OES } & \text { outer enamel surface } \\ \text { P } & \text { prism } \\ \text { pad } & \text { paraconid } \\ \text { pald } & \text { paralophid } \\ \text { prd } & \text { protoconid } \\ \text { prld } & \text { protolophid } \\ \text { RE } & \text { radial enamel } \\ \text { REIS } & \text { radial enamel with thin inter-row sheets } \\ \text { RETS } & \text { radial enamel with twisted inter-row sheets }\end{array}$

\section{Institutional abbreviations}

KOE enamel collection of the Institute of Geosciences, Section Paleontology, Rheinische FriedrichWilhelms-Universität Bonn, Bonn, Germany

UCM University of Colorado Museum of Natural History, Boulder, Colorado, USA

UNAM Colección Nacional de Mamíferos (CNMA) of the Instituto de Biologia, Mexico

UTCM University of Tennessee, Chattanooga, USA

\section{Results}

\section{The schmelzmuster of Megasorex gigas}

The schmelzmuster of Megasorex gigas (Text-figs 2-5) seems to be almost uniform on the first glimpse. It appears to be one-layered and formed exclusively by radial enamel only. However, a more detailed investigation finds a slight differentiation in the innermost zone of the enamel close to the EDJ. There, the prisms are better seen in cross-section, indicating that they are steeply rising. They are partially arranged in rows with inter-row sheets. This differentiated

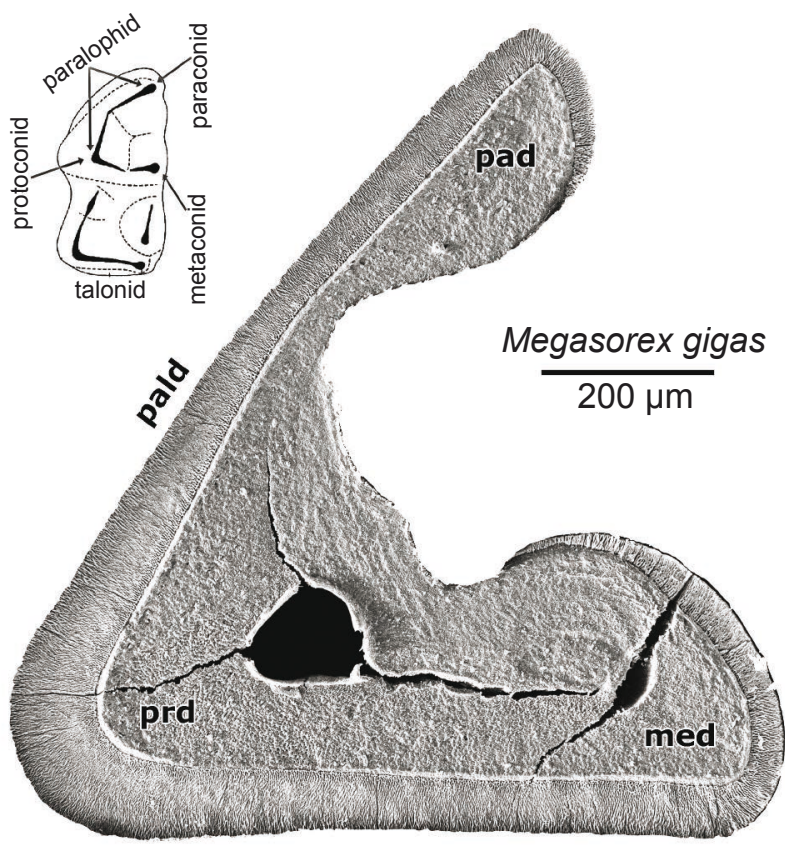

Text-fig. 2. Megasorex gigas, cross-section of the trigonid of the left $\mathrm{m} 1$ (UNAM 43090, KOE 4222). In the schmelzmuster radial enamel is dominant, but a thin inner layer is recognizable. Abbreviations: med - metaconid, pad - paraconid, prd protoconid.

innermost layer is observable all around the trigonid and was observed in higher parts of the crown as well. Although thin, this innermost layer is significant, because it resembles the inner layer of radial enamel with inter-row sheets (REIS) that was found by Koenigswald and Reumer (2010) in the related Notiosorex crawfordi (KOE 2114) and many other Soricinae. The single rows of prisms in Megasorex, however, are fairly short, and therefore no distinct layer of REIS is present. Beyond this innermost layer, the prisms rise less steeply and are not well separated from the IPM, forming a typical radial enamel. In the outermost third, the prisms are seen more in cross-section, again indicating that they rise more steeply towards the OES. In the buccal side of the prld, a limited deflection is recognizable. Such an inclination of the outer layer towards the lingual side was observed in many soricids. In summary, the two-layered schmelzmuster of Megasorex is dominated by radial enamel. The qualification of being two-layered is mainly due to the similarity to the related Notiosorex.

\section{The schmelzmuster of Cryptotis magna}

In comparison to Megasorex gigas, the schmelzmuster of Cryptotis magna is undoubtedly two-layered (Text-figs $3,4)$. In the inner layer, prisms and IPM are well exposed, whereas the outer layer shows prisms only in cross-section, representing a radial enamel. The enamel of the outer layer stands slightly higher than the inner one, due to the etching. It is a common observation that pigmented enamel etches less (Dötsch and Koenigswald 1978).

In the inner layer, prisms are arranged in rows separated by sheets of IPM. This radial enamel with inter-row sheets (REIS) is a derived character in soricid enamels. In the 

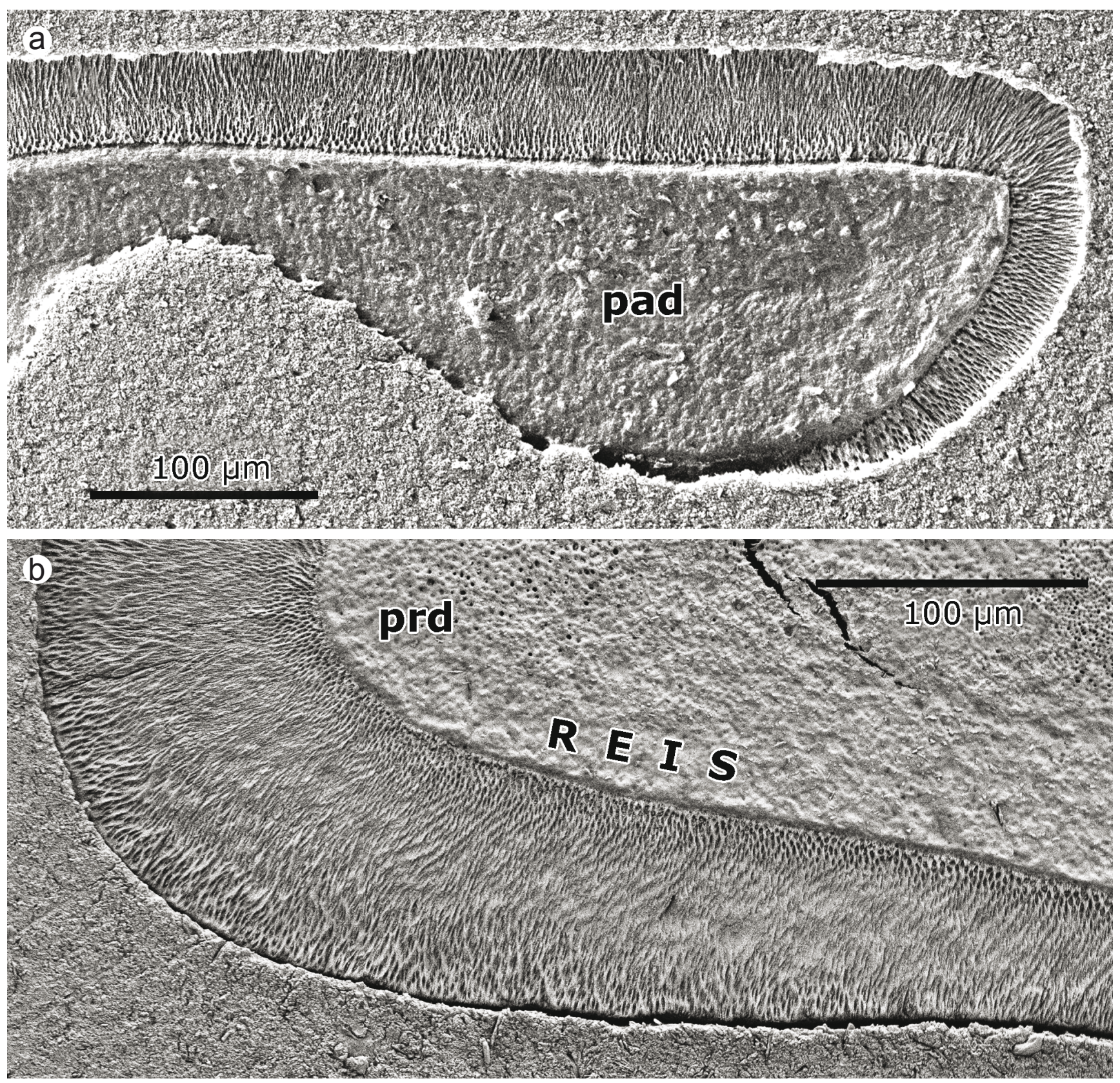

Text-fig. 3. Megasorex gigas, details of the schmelzmuster. a) Enamel of the protoconid in cross-section. Note the very thin inner layer of prisms that are partially separated by inter-row sheets (REIS). b) enamel of the paraconid showing only radial enamel. Abbreviations: pad - paraconid, pald - paralophid, prd - protoconid.

buccal half of the paralophid, the prisms are inclined towards the protoconid (prd) (Text-fig. 5a). The rise of the prisms is minimal, and the sheets of the IPM are more obvious. The crystallites of the IPM are oriented perpendicularly to the prisms. In the prd, the fields of inclined prisms from the pald and prld come together, and in the zone between the fields, the orientation of the prisms is radial. In the lingual parts of the prld and pald, the inclination of the prisms towards the paraconid (pad) and metaconid (med), respectively, is less intense. The outer layer is formed by radial enamel. This is somewhat surprising, because in Cryptotis parva (KOE 4197), a more intensive inclination towards pad and med was observed (Koenigswald and Reumer 2010), as in most soricid molars that are assigned to the Blarina-schmelzmuster. In the typical Blarina-schmelzmuster, prisms are inclined so strongly that the enamel looks like a tangential enamel. Whether the lack of this inclination in the examined specimen of Cryptotis magna represents an individual variation, or whether it is a characteristic of real taxonomic significance, can only be decided after more teeth are investigated. Despite this minor difference, the structure of the inner layer on the buccal side with the intense lateral inclination allows me to assign Cryptomys magna to the Blarina-schmelzmuster.

\section{Discussion}

The different arrangement of enamel types found in Cryptotis and Megasorex require comparison to various types of schmelzmuster discovered in soricids and other insectivorous mammals (Koenigswald and Reumer 2020). 


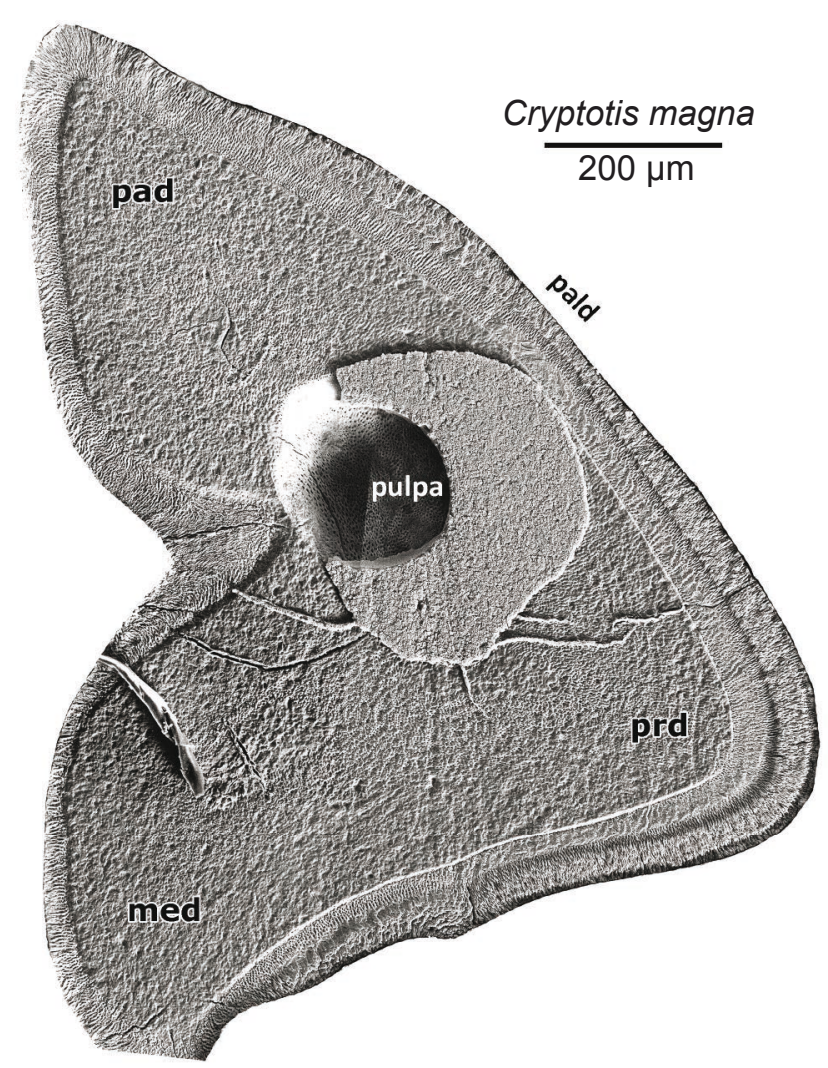

Text-fig. 4. Cryptotis magna cross-section of the trigonid of the right $\mathrm{m} 1$ (UNAM 29439, KOE 4220). The schmelzmuster is two-layered. Abbreviations: med - metaconid, pad paraconid, pald - paralophid, prd - protoconid.

The wide survey of shrew enamel by these authors identified six types of schmelzmuster in the lower molars, which shows an increasing complexity with phylogenetic specialization. The primitive condition for soricid enamel (here denoted as Soricella-schmelzmuster) is single-layered and of radial enamel (RE). Prisms rise from the EDJ in a radial direction towards the OES. In the trigonid of lower molars, the RE may show a slight deflection in the paralophid (pald) as well as in the protolophid (prld). The prisms and the IPM bend slightly to the lingual side. In SEM photos, the area of deflection shows a more intensive reflection than the normal RE. The deflection is often retained if the RE is restricted to the outer layer. It is, however, often obscured if the pigmentation modifies the etching. The deflection is not a unique structure of Soricidae, but occurs in several other Eulipotyphla too ( e.g. in Talpa).

During evolution, the single-layered schmelzmuster gave rise to different kinds of structural modifications (Textfig. 6). Originating in the Soricella-schmelzmuster, three different pathways are seen in the Crocidura-, Anourosorexand Notiosorex-schmelzmuster. From the Notiosorexschmelzmuster, the soricines differentiated their enamel into the Sorex- and Blarina-schmelzmuster.

They can be characterized as follows (Koenigswald and Reumer 2020):

The basal Soricella-schmelzmuster is one-layered and consists of RE only. It was observed within Soricidae in Allosorex, Florinia, Lartetium, Miosorex, Paenelimnoecus, Paenesorex, "Petenyia" dubia, Soricella and Ulmensia. The same schmelzmuster occurs in heterosoricids. The similarity in the schmelzmuster is a primitive character, because it occurs in several other Eulipotyphla and Chiroptera. The wide distribution of the Soricella-schmelzmuster marks the most primitive level in Soricidae.

In comparison to the Soricella-schmelzmuster, the Crocidura-schmelzmuster shows a slight differentiation. It is basically one-layered and formed by RE. But in sections where the enamel band is brought, an inner zone of typical radial enamel can be separated from an outer zone. In the outer zone, the prisms are difficult to identify. There, the prism sheath is gradually dissolved, and the prisms are no longer recognizable in the IPM. This schmelzmuster was found in Crocidura, Limnoecus, Myosorex, and Suncus, but the thickness of the outer zone varies, and is almost totally missing in Paracrocidura.

The Anourosorex-schmelzmuster is one-layered and characterized by RE forming a thick enamel band. However, the outermost part of the RE close to the OES shows some differentiation. In sections where the enamel band curves strongly, the prisms turn sideways. This somewhat irregular bending occurs together with the IPM, forming radial enamel with twisted inter-row sheets (RETS). In other parts, the radial enamel penetrates to the OES. The Anourosorexschmelzmuster was found not only in the extant Anourosorex, but in the late Miocene genera Paranourosorex, Crusafontina and Kordosia. The specific schmelzmuster, although its differentiation is small, provides an argument for excluding Anoursoricini from Soricinae (Van Dam 2008, 2010).

The Notiosorex-schmelzmuster is characterized by an inner layer formed by REIS, but in contrast to the other twolayered types of schmelzmuster, this inner layer is very thin. In the thick outer layer, the deflection is very visible. This schmelzmuster was established in Notiosorex, but according to this paper, it is present also in Megasorex, the second genus of the tribe Notiosoricini.

In the Sorex-schmelzmuster, the inner layer is thicker and is formed by REIS. In lower molars, the REIS is slightly inclined towards the buccal side near the prd, but more intensively to the lingual side close to pad and med. The following genera show the Sorex-schmelzmuster: Neomysorex, Nesiotites and Sorex. The various species of Sorex vary in the extent of the inclined fields of the inclined REIS.

In the Blarina-schmelzmuster, the complexity of the Sorex-schmelzmuster increases. The entire length of the enamel band shows inclined REIS. Where the two fields of differently inclined REIS meet, a neutral point occurs. The Blarina-schmelzmuster was found in the following genera: Alloblarinella, Asoriculus, Beremendia, Blarina, Blarinoides, Chimarrogale, Cryptotis, Deinsdorfia, Dolinasorex, Episoriculus, Neomys, Zelceina.

The schmelzmuster found in Megasorex gigas (Text-figs 2,3 ) conforms broadly to that of Notiosorex crawfordi, but shows some informative differences. The inner layer shows less REIS and is not well separated from the outer layer. It confirms the basal position of the Notiosorex-schmelzmuster deriving from a single-layered schmelzmuster, such as the Soricella-schmelzmuster. The more basal Notiosorexschmelzmuster differs distinctly from the highly derived Blarina-Schmelzmuster found in Neomys. This difference provides an additional argument for separating tribes Nectogalini (= Neomyini) and Notiosoricini. 

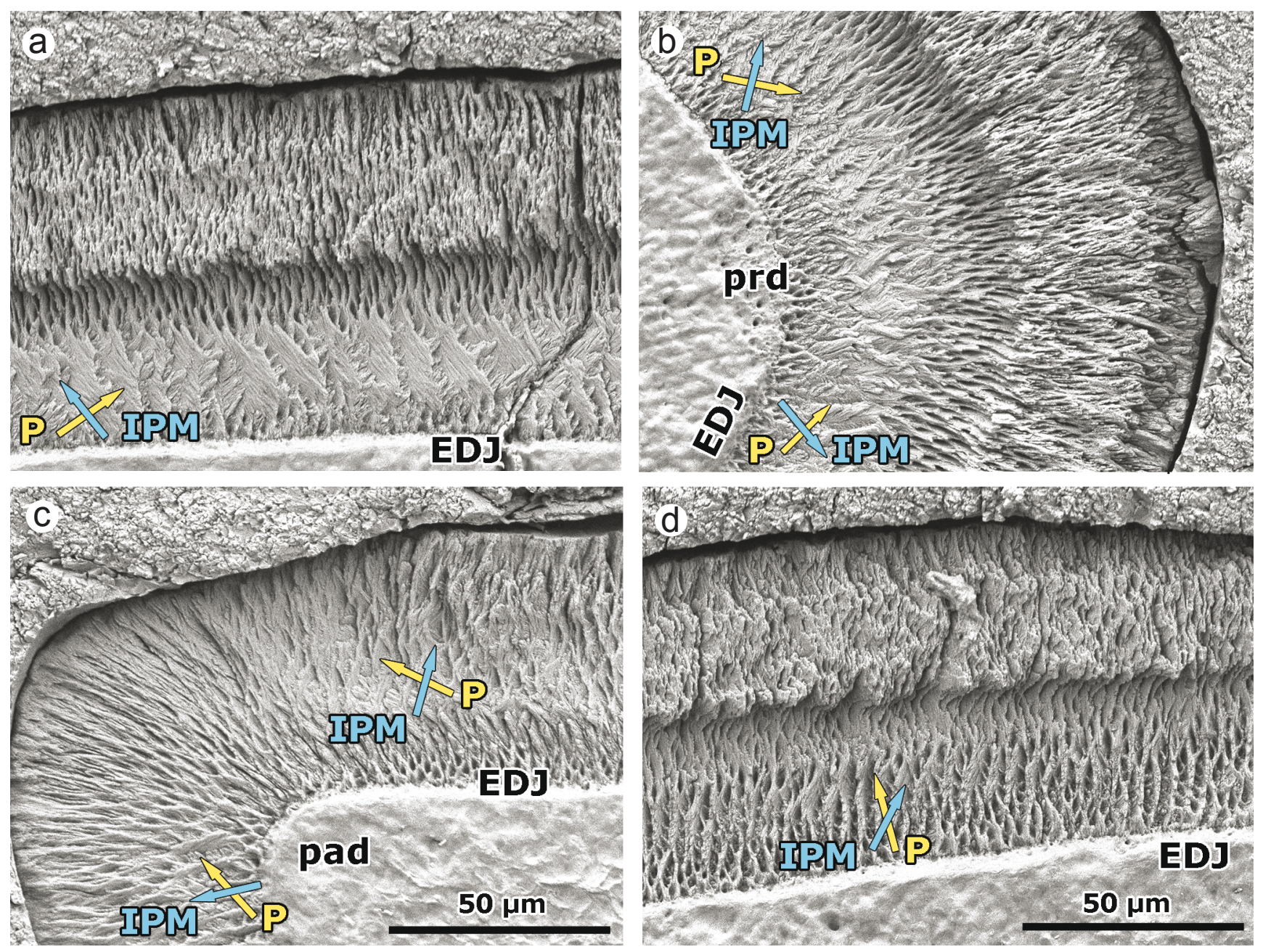

Text-fig. 5. Cryptotis magna, details of the schmelzmuster. a) Detail from the pald more closely to the prd. The REIS of the inner layer is strongly inclined to the right (prd). Because the prisms are almost horizontal, the IPM occurs as a sheet between the rows of prisms. The crystallites of the IPM are perpendicular to the direction of prisms. b) In the protoconid, the two-layered enamel is obvious. In the inner layer, prisms are inclined from both sides, from the pald and prod. The IPM is almost perpendicular to the prisms. The outer layer is of radial enamel. c) The paraconid shows slightly inclined prisms and IPM, and most is radial enamel. d) Detail from the pald. The inner layer is formed by radial enamel with inter-row sheets (REIS). In the left part of the picture, a minimal inclination towards the left (pad) is recognizable. The outer layer is composed of radial enamel. Note the step close to the margin between the two enamel types. It is caused by pigmentation in the outer layers, which hinders the etching. Abbreviations: EDJ - enamel dentine junction, IPM - Interprismatic matrix, p - prisms, pad - paraconid, prd - protoconid.

The Blarina-schmelzmuster found in Cryptotis magna agrees with that in the smaller species Cryptotis parva. The intensive inclination in the buccal part of the pald shows a great resemblance to the Blarina-schmelzmuster, even if the inclination near the pad is reduced. That may indicate a specialty of that genus.

Cryptotis and Megasorex differ not only in the schmelzmuster of their molars, but also in the pigmentation of their tooth cusps. Although both genera belong to Soricinae, which generally have pigmented teeth, Megasorex has unpigmented teeth. This character, and its relatively simple schmelzmuster, might invite a comparison with the unpigmented teeth of crocidurines, raising the question of whether the lack of coloring is reflected in the schmelzmuster.

The similarity of the schmelzmuster in Megasorex and Crocidura is misleading and superficial. The inner layer observed in Notiosorex and Megasorex is missing in the single-layered Crocidura-schmelzmuster. The vanishing prism sheaths of the prisms near the OES that characterize the Crodidura-schmelzmuster were not found in Megasorex. Thus, there is no indication that the lack of coloring has an effect on the schmelzmuster.

The superficial similarity of the schmelzmuster of Megasorex and Crocidura can be explained differently. Megasorex is attributed to the Notiosorex-schmelzmuster, and holds a very basal position in the soricine lineage, retaining characters from the Soricella-schmelzmuster. The Crociduraschmelzmuster, on the other hand, did not intensively modify the basal Soricella-schmelzmuster. Therefore, the shared appearance reflects the limited modification.

Nectogale, a rare Chinese soricine with white teeth, could provide an additional argument, but unfortunately, it could not be investigated. Neomys, a member of the same tribe, represents the highly-derived Blarina-schmelzmuster, which is therefore to be expected for Nectogale as well.

The pigmentation of the enamel is due to the deposition of iron in the outer layer (Dötsch and Koenigswald 1980, Dumont et al. 2014, Moya-Costa et al. 2019). In Soricidae, 


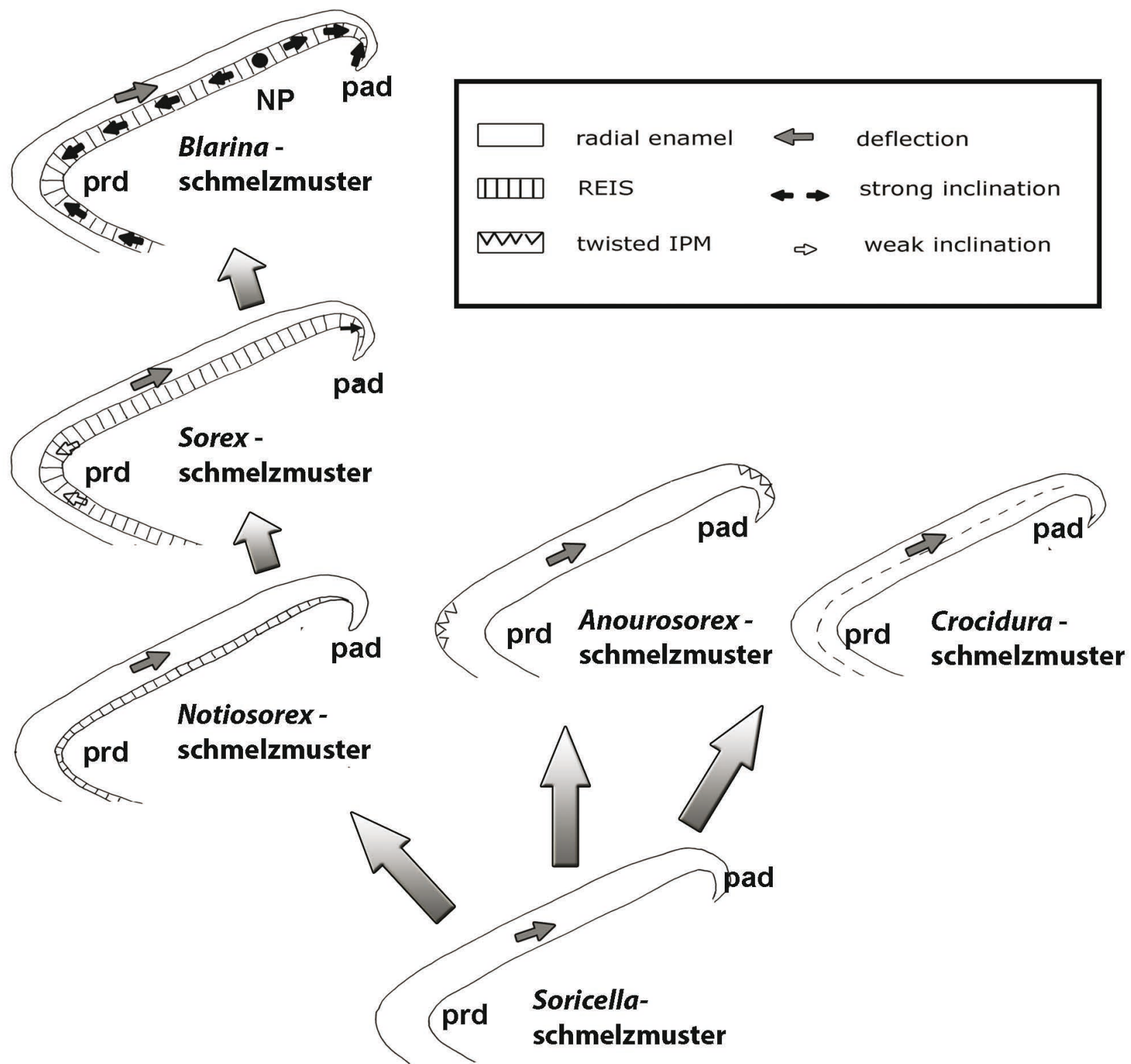

Text-fig. 6. Increasing complexity in the six differentiated types of schmelzmuster. The single-layered schmelzmuster is the most primitive stage in Soricidae. Crocidurinae and Anourosoricini modified this basal schmelzmuster only slightly, whereas the Soricinae evolved a two-layered schmelzmuster with REIS, and a varying lateral inclination (from Koenigswald and Reumer 2020). Megasorex represents the Notiosorex-schmelzmuster and Cryptotis the Blarina-scmelzmuster. Abbreviations: NP - neutral point between inclined fields, pad - paraconid, prd - protoconid.

the loss of pigmentation is regarded as a derived character (Repenning 1967, Vogel 1984), which happened several times independently.

\section{Conclusion}

The two Mexican soricids Megasorex and Cryptotis differ distinctly in their schmelzmuster. Megasorex is characterized by the Notiosorex-schmelzmuster, whereas Cryptotis has the Blarina-schmelzmuster.

The two-layered Notiosorex-schmelzmuster represents the lowest differentiation within the Soricinae, and Megasorex demonstrates details comparable to the initial single-layered Soricella-schmelzmuster, from which Soricinae and Crocidurinae originated. In contrast, the differentiated schmelzmuster of Cryptotis represents the Blarina-schmelzmuster. It shows the highest degree of enamel differentiation in the molars of Soricinae.

Enamel microstructure provides an additional set of characters to understand the evolution of shrews. The basic pattern was described with the differentiation of the six types of schmelzmuster (Koenigswald and Reumer 2020), but the modifications found in Cryptotis and Megasorex indicate a somewhat higher variability. A more complete picture may become apparent when the great number of soricid genera are better known by their molar enamel. The schmelzmuster of the procumbent incisors may provide additional information. The increasing knowledge of the enamel microstructure may shed new light on the evolution of soricids and their expansion from one continent to the 
other. The enamel, however, cannot give definitive answers to questions about changes in diet or the environment.

\section{Acknowledgements}

I am deeply indebted to Fernando A. Cervantes Reza, who provided the material of Megasorex and Cryptotis for this study. Marisol Montellano helped to spot the material and Jan Decher (Forschungsinstitut Alexander Koenig, Bonn) enabled shipping of the materials to Bonn. Timothy J. Gaudin (UTMC) provided additional soricid material from Tennessee. Nicole Neu-Yagle and Emily Braker provided the photo of the UCM specimen of Notiosorex crawfordi. Jaelyn J. Eberle (UCM) visited Bonn University to study enamel of rhinos. The intensive discussions about enamel microstructures were inspiring and a great pleasure. She kindly read and corrected the English version. During my studies, I gratefully appreciate great technical support from Olaf Dülfer, Peter Göddertz, Carola Kubus, and Georg Oleschinski (Institut für Geowissenschaften der Universität Bonn).

\section{Literature}

Carraway, L. N. (2010): Fossil history of Notiosorex (Soricomorpha: Soricidae) shrews with descriptions of new fossil species. - Western North American Naturalist, 70(2): 144-163. https://doi.org/10.3398/064.070.0202

Cervantes, F. A., Montiel, A., Garciá, A. (2008): Shrews (Mammalia, Sorcimoprha) from Colima, Mexico. Southwestern Naturalist, 53(1): 101-129. https://doi.org/10.1894/0038-4909(2008)53[101:SMSF $\mathrm{CM}] 2.0 . \mathrm{CO} ; 2$

Dötsch, C., Koenigswald, W. v. (1978): Zur Rotfärbung der Soricidenzähne. - Zeitschrift für Säugetierkunde, 43: 65-70.

Dubey, S., Salmin, N., Ohdachi, S. D., Barrière, P., Vogel, P. (2007): Molecular phylogenetics of shrews (Mammalia: Soricidae) reveal timing of transcontinental colonizations. - Molecular Phylogenetics and Evolution, 44: 126-137. https://doi.org/10.1016/j.ympev.2006.12.002

Dumont, M., Tütken, T., Kostka, A., Duarte, M. J., Borodin, S. (2014): Structural and functional characterization of enamel pigmentation in shrews. - Journal of Structural Biology, 186: 38-48. https://doi.org/10.1016/j.jsb.2014.02.006

Gunnell, G. F., Bown, T. M., Hutchinson, H., Bloch, J. I. (2008): Lipthyphla. - In: Janis, C. M., Gunnell, G. F., Uhen, M. D. (eds), Evolution of Tertiary Mammals of North America, Vol. 2. Cambridge University Press, Cambridge, New York, Port Melburne, Madrid, Cape Town, pp. 89-125.

Harris, A. H. (1998): Fossil history of shrews in North America. - In: Wójcik, J. M., Wolsan, M. (eds), Evolution of Shrews. Mammal research Institute, Polish Academy of Sciences, Białowieza, pp. 133-156.

Hibbard, C. W. (1950): Mammals of the Rexroad Formation from Fox Canyon, Kansas. - Contributions from the Museum of Paleontology, University of Michigan, 8(6):113-192.

Hutterer, R. (2005): Soricidae. - In: Wilson, D. E., Reeder, D. M. (eds), Mammal Species of the World: A Taxonomic and Geographic Reference ( $3^{\text {rd }}$ ed.). Johns Hopkins University Press, pp. 267-300.

Koenigswald, W. v., Clemens, W. A. (1992): Levels of complexity in the microstructure of mammalian enamel and their application in studies of systematics. - Scanning Microscopy, 6(1): 195-218.

Koenigswald, W. v., Reumer, J. (2020): The enamel microstructure of fossil and extant shrews (Soricidae and Heterosoricidae, Mammalia) and its taxonomical significance. - Palaeontographica, A, 316: 79-164.

Moya-Costa, R., Cuenca-Bescós, G., Bauluz, B., Rofes, J. (2018): Structure and composition of tooth enamel in quaternary soricines (Mammalia). - Quaternary International, 481: 52-60. https://doi.org/10.1016/j.quaint.2017.04.039

Repenning, C. A. (1967): Subfamilies and genera of the Soricidae. - Geological Survey Professional Paper, 565: $1-74$. https://doi.org/10.3133/pp565

Reumer, J. W. F. (1984): Ruscinian and early Pleistocene Soricidae (Insectivora, Mammalia) from Tegelen (The Netherlands) and Hungary. - Scripta Geologica, 73: $1-173$.

Reumer, J. W. F. (1996): The effect of paleoclimate on the evolution of the Soricidae (Mammalia, Insectivora). In: Vrba, E. S., Denton, G. H., Partidge, T. C., Burckle, L. H. (eds), Paleoclimate and Evolution, with Emphasis on Human Origins. Yale University Press, New Haven and London, pp. 135-147.

Reumer, J. W. F (1998): A classification of the fossil and recent shrews. - In: Wójcik, J. M., Wolsan, M. (eds), Evolution of Shrews. Mammal research Institute, Polish Akademy of Sciences, Białowieza, pp. 5-22.

Rzebik-Kowalska, B. (2009): Biodiversity of Polish fossil insectivores (Erinaceomorpha, Soricomorpha, Insectivora, Mammalia) compared to the European and global faunas. - Institute of Systematics and Evolution of Animals, Polish Academy od Sieces, Kraków, 123 pp.

Špoutil, F., Vlček, V., Horáček, I. (2010): Enamel microarchitecture of a tribosphenic molar. - Journal of Morphology, 271: 1204-1218. https://doi.org/10.1002/jmor.10867

Van Dam, J. (2008): Anourosoricini (Mammalia: Soricidae) from the Mediterranean region: A pre-Quaternary example of recurrent climate-controlled north-south range shifting. - Journal of Paleontology, 78: 741-764. https://doi.org/10.1666/0022-3360(2004)078<0741: AMSFTM $>2.0 . \mathrm{CO} ; 2$

Van Dam, J. (2010): The systematic position of Anourosoricini (Soricidae, Mammalia): paleontological and molecular evidence. - Journal of Vertebrate Paleontology, 30(4): 1221-1228. https://doi.org/10.1080/02724634.2010.483553

Vogel, P. (1984): Verteilung des roten Zahnschmelzes im Gebiss der Soricidae (Mammalia, Insectivora). - Revue suisse de Zoologie, 91: 699-708. https://doi.org/10.5962/bhl.part.81575 